UDC 811.111

DOI: $10.17223 / 24109266 / 8 / 10$

\title{
“HEY, WHAT'S YOUR NAME?": ANTHROPONYMICS \\ IN THE LANGUAGE PICTURE OF THE WORLD OF JIM MORRISON
}

\author{
B.Ya. Sharifullin \\ Lesosibirsk Pedagogical Institute (Lesosibirsk, Russian Federation) \\ E-mail: borshariff@gmail.com
}

No one remembers your name

When you're strange

"People are strange"

\begin{abstract}
In the article, the anthroponyms are considered as one of the key fragments of the language picture of the world of American poet and musician Jim Morrison. The symbolism of names, which is important for all lingual cultures, in the poetics of Jim Morrison is manifested in a special way, because of his specific perception of the people, especially the women, with whom Jim Morrison's relations were not the simple due to a specific life of rockmusician in California of the flower revolution epoch. In the Jim Morrison's linguistic picture of the world, the elements of European (Antique, Germanic, Celtic) culture and culture of North American Indians are invented. Jim Morrison has created also his own cultural code, the American one, more exactly, a code of California, and the appropriate poetics of myths, that are reflected in his poetic texts. Therefore, the anthroponyms in the lyrics by Jim Morrison reflect all these cultural codes. In the article, the most interesting cases of inclusion of the anthroponyms in his lyrics are presented. English quotations from the songs are accompanied by Russian translations made by the author.

Keywords: language picture of world; cognitive and typological reconstruction; symbolism of name; anthroponyms; Jim Morrison; The Doors.
\end{abstract}

\section{Introduction}

This article continues the series of studies on cognitive and typological reconstruction of Jim Morrison's, the American poet and musician and the leader of rock-group "The Doors", language picture of the world [1-3].

The onomastic space of songs texts by Jim Morrison is not so high if compared, for example, with the texts of "the Beatles" [4]. The place names are represented much more than anthroponyms, which, in general, is understandable: in Morrison's language picture of the world the space is represented very much by what we see in the images of the sea, road, city and country (e.g., see [5]). A small number of anthroponyms in Morrison's texts is due, probably, to his words that are presented in the epigraph to this article: "No one remembers your name when you are strange people". I note that the English word strange can be translated as "stranger". 
Still, let it be small research but about women's and men's, and especially about women's names, meaning the very peculiar way that the women are represented in the poetics of Jim Morrison, which reflects his personal life and poetic creativity [2].

About onomastics as a linguistic symbol in the lyrics of British rock poetry I wrote earlier (see [6]). In this article it will be reviewed on the material of Jim Morrison' lyrics, and that is its purpose.

\section{The research methods}

The main research method in this article is a semantic-mythopoetic interpretation of textual material. The comparative textual analysis and methodology of translation and interpretation of the text are also used.

\section{The investigation}

\section{1. 'Roll on, roll on, Maggie M'Gill'. Feminine names in Jim Morrison's songs}

Hello, I love you, won't you tell me your name

Jim Morrison had an uneasy relationship with women, which is associated with the well-known characteristics of a rock musician in California at the era of the "revolution of flowers" and "children of love". "Sex, drugs \& Rock'n Roll", "Make love, not war" - those were not just slogans, it was a way of life. And the groupies of the band "Doors" were not like the girl-fans of uthe Beatles". So Jim had a lot of girls and women, a lot of music, whiskey, drugs, and poetry...

In fact, the only and the last beloved woman and the Muse of Jim Morrison was Pamela Courson, whose surname in Russian is often passed as Курсон, or even Корсон, Корзон). He dedicated to her many poems and some of the most beautiful of his songs (e.g. "Love Street", "Indian Summer", "My Eyes Have Seen You", "Twentieth Century Fox", "L.A. Woman", "Queen of the Highway", "Wild Child", and "Orange County Suite", which is directly related to the flaming hair of Pamela). Morrison met this beautiful red-haired and green-eyed girl at a party in September 1965, and was constantly in her company, which, however, did not prevent him to tie a fleeting romance with his many female fans, groupie girls. But he loved Pamela sincerely and called her his "cosmic friend" [7] (Fig. 1).

Pamela, just like Jim died at 27 years old, having survived him only 3 years... But Jim nowhere in his poetry mentioned Pamela's name, unlike John Lennon's Muse, Yoko Ono, whose name is found frequently in Lennon's songs. It was, probably, because Jim wrote about Pamela in his poems, not all of which later became songs. And in verses, it is not accepted to men- 
tion the name of the beloved one, it is simply implied. Our Pushkin also wrote "To K...".

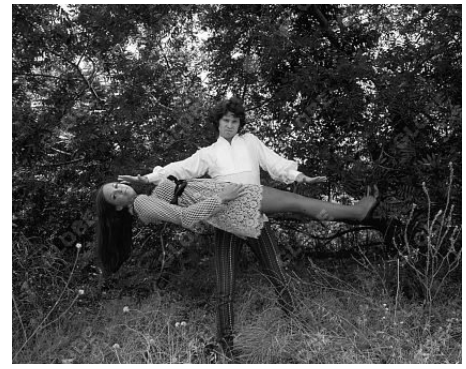

Fig. 1

Morrison often uses the pronoun she and its forms and also the form of the pronoun of the second person you, as in one of the best songs, "Love Street", 1968. Here is the full text:

She has robes and she has monkeys

Lazy diamond studded flunkies

She has wisdom and knows what to do

She has me and she has you

I see you live on Love Street

There's this store where the creatures meet

I wonder what they do in there

Summer Sunday and a year

I guess I like it fine, so far

She lives on Love Street

Lingers long on Love Street

She has a house and garden

I would like to see what happens (Fig. 2).

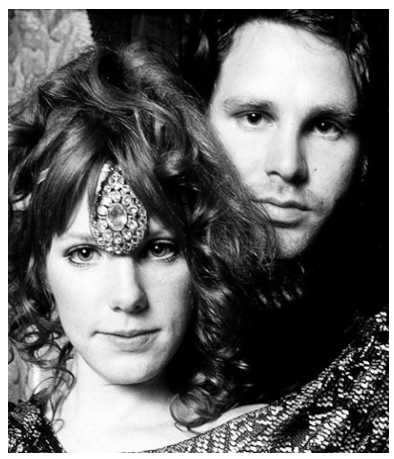

Fig. 2 
Originally, this song was a poem written by Jim Morrison about the street in the Laurel Canyon area of Los Angeles, California, where he lived with Pamela. Morrison and Courson called this street the Love Street, because they were sitting on the balcony and watched countless hippies who were passing by, constantly kissing (Fig. 3). A store, referred to, was in the house opposite [7].

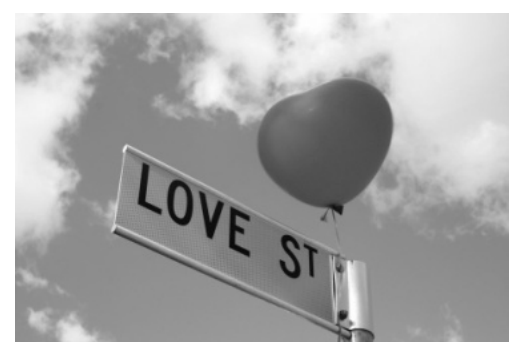

Fig. 3

Some of the women's names in Morrison's texts, otherwise, allow us to correlate them with Pamela as, for example, in his song ("Maggie M Gill", an album "Morrison Hotel", 1970):

Miss Maggie M'Gill, she lived on a hill.

Her daddy got drunk and left her the will.

So she went down, down to Tangie Town.

People down there like to get it on.

What facts can testify in favor of this assumption? First, the Irish surname M'Gill (and Pamela was of Irish descent; in the Oliver Stone's movie, "The Doors", she was played by Meg Ryan, also of Irish descent), more precisely, MacGill, Magill, from Gaelic MacanGhaill that means "son of the stranger" [8: 296]. The name Pamela as one of the versions is, translated from Latin "wanderer".

Secondly, on the cover of the single of the song there is the photo of a red-haired girl with a guitar, very similar to Pamela, in particular, due to the shape of the nose in profile (Fig. 4, 5):

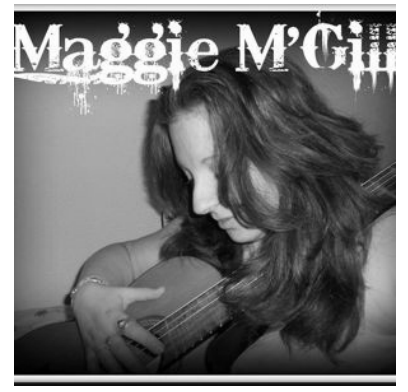

Fig. 4 


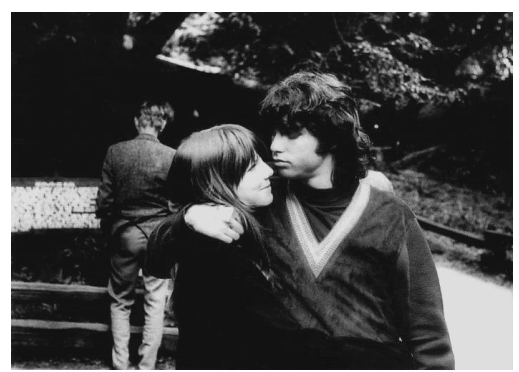

Fig. 5

Unfortunately, I didn't find any information about who is on the cover. "Wikipedia" only mentioned that this song is dedicated to Pamela Courson.

The onomastic game is used by Jim Morrison in his song "Stoned Immaculate", from the album "An American Prayer", 1978:

One summer night, going to the pier

I ran into two young girls

The blonde one was called Freedom

The dark one, Enterprise

We talked and they told me this story

Now listen to this...

The essence of the game is that the English word freedom is "freedom", and enterprise is "business". Freedom, of course, is all "white" (like the statue of Liberty in New York), and the business, apparently, is "dark".

There is the name Freedom in the United States, and it is quite popular, but it is considered as a man's name, anyway, according to the Internet, which, in general, is strange, as we see the female appearance of the famous statue. But I did not find the female name Enterprise, so the ironic play by Morrison is obvious: the opposition of liberty and business, black and white.

There are also four female names in Morrison's texts which can be considered as "looping": Sandy, Carol, Gloria and Wanda.

The Man is at the door

Peppermint, miniskirts, chocolate candy

Champion sax and a girl named Sandy

("The Soft Parade", album "Soft Parade", 1969).

The name Sandy, qualitative of Alexandra (and of the corresponding form of the male name), was quite common in the 60-70s of the last century in Britain and America, especially in the genres of music like country, folk and rock. Therefore, this name used by Jim can be generalized to denote a typical "girl-groupie", constantly hanging out at various music events. But it can be assumed as an allusion to the popular British rock and folk-singer and composer, Sandy Denny (Alexandra Helen McLean Denny; 6 January 1947 21 April 1978) [https://ru.wikipedia.org/wiki/Денни Сэнди]. Jim Morrison certainly knew about her and her work; especially in their poetics there were 
similar motives (Celtic folklore). It interesting to compare the meanings of the titles of the songs by Jim Morrison "Waiting for the sun" and Sandy Denny's "Rising for the moon" ("the sun" and "moon"), although the impact here was likely from Jim: the song of Sandy Denny represented in the eponymous album, "Fairport Convention" in June 1975. By the way, Sandy was also red-headed (Fig. 6):

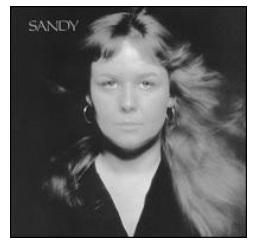

Fig. 6

Some onomastic game, perhaps not deliberately provided by Morrison, is presented in a rather long song "Gloria" ("An American Prayer", 1978; quoted in abbreviated form):

Did you hear about my baby?

She come round here, the head to the ground,

Come round here just about midnight,

She makes me feel so good, make me feel all right.

She come round my street, now

She come to my house and

Knock upon my door

Climbing up my stairs, one, two

Come on baby

Here she is in my room, oh boy

Hey what's your name?

How old are you?

Where'd you go to school?

Well, now that we know each other a little bit better,

Why don't you come over here

Make me feel all right!

Gloria, Gloria - all night, all day

Gloria, Gloria

You were my queen and I was your fool,

Riding home after school.

You took me home to your house.

Your father's at work,

Your mama's out shopping around.

Check me into your room.

Show me your thing. 
Why'd you do it baby?

Getting softer, slow it down

Now you show me your thing.

Wrap your legs around my neck,

Wrap your arms around my feet, yeah

Wrap your hair around my skin.

I'm gonna huh, right, ok, yeah.

It's getting harder, it's getting too darn fast

Come on, now, let's get it on.

Too late, too late, too late, can't stop, wow!

Female name Gloria in Latin means literally "glory". Judging by the content of the song, we are talking about one of the young girl-groupies (even a schoolgirl) who crowded around Jim. The song is very sexual, as evidenced by its execution. But the game perhaps lies in the fact that this girl, Gloria, of course, was attracted, first of all, by Morrison' glory. Maybe Jim has outlined one of the many girl-groupies whose names he didn't remember - Gloria. A kind of irony? It is quite likely as it often was characteristic for Jim Morrison.

About the name Carol, that appears in the eponymous song ("Carol", “An American Prayer", 1978):

\section{Oh, Carol!}

Don't let him steal your heart away.

Yeah I've got to love you darling

If it takes me all night and day.

Beat cool down, over cool down,

I can hear that highway sound.

Carol!

Most likely, it's again about one of the girl-groupies. The name Carol was fairly common in America in those days (the short form of Carolina, the feminine form of the masculine name Carlus, the English version, Charles, which came from the German Emperor Carolus, from where, by the way, came the Slavic word король). Here is a picture of typical girl-groupies (of the rock group "Kiss") (Fig. 7).

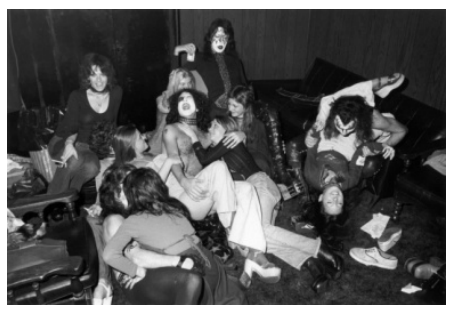

Fig. 7 
The name Wanda was used only in one of the fragments of Jim Morrison's poem, "The Paris Journal" (1972):

Shake it! Wanda,

fat stranded swamp.

Woman,

We still need you.

The name Wanda is of Polish origin, from old Slavonic word meaning "troublemaker, argumentative". I haven't found information, whether Morrison is referring to a particular woman, Wanda, or whether it is just a collective image of the Slavic women, who had a reputation in those days in the West as thickset and clumsy. Note that this is also the name of the heroine of the American comedy thriller of 1888 "A fish named Wanda", a role of Jamie Lee Curtis; the surname of her heroine was by the way Jewish, Herschwitz, from Poland).

\section{2. "Poor Otis dead and gone". Masculine names in Jim Morrison's songs}

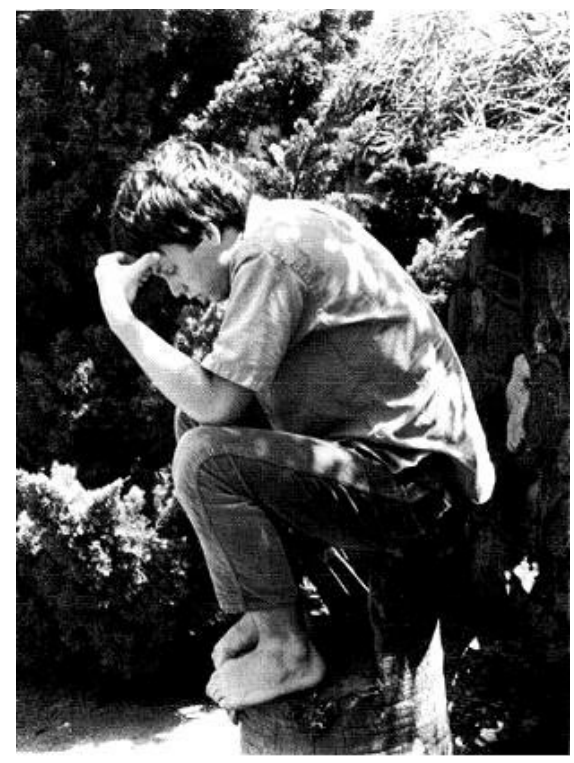

Fig. 8

Of all the masculine anthroponomy we found in the lyrics by Jim Morrison, the interesting is only one (Fig. 8), demonstrating an inherent Jim's creative speech onomastic game. But first, let us consider some more banal examples, and there are quite a few.

In the song "Hyacinth House" from the album "L.A. Woman" the name Jack in English playing card terminology means The Jack (see also jack pot): 
Why did you throw the Jack of Hearts away?

It was the only card in the deck that I had left to play.

So here, in fact, we meet not an anthroponym, but a common name, although according to the rules of English orthography it is written with a capital letter. Also note that the name Jack (from diminutive John, i.e. like Russian Ваня) has also the additional nominal value, including, word combinations and complex words. Often these words are written with a lowercase letter: for example, jackass "donkey, fool, idiot" (that's the equivalent of our Ivan the fool), etc.

In the song "Ship of fools" ("Morrison Hotel", 1970) there is a character whose name, Mr. Goodtrip, is "speaking", which is the result of Jim's onomastic games:

Yeah, along came Mr. Goodtrips

Lookin' for a new a ship.

Come on, people better climb on board.

Come on, baby, now we're goin' home.

Ship of fools...

We meet the name Otis in the composition "Runnin' Blue" from the album "Soft Parade" (1969):

Poor Otis dead and gone

Left me here to sing his song

Pretty little girl with the red dress on

Poor Otis dead and gone...

This is the name of a famous American singer and composer in the genre of soul music, Otis Ray Redding, who was tragically killed in a plane crash in 1967 at the age of 26 years (Fig. 9). His work influenced the music of the Rolling Stones, George Harrison, Marvin Gaye and others. I think Jim Morrison was influenced too, if he wrote that Otis "left me here to sing his song". "Girl with the red dress on" is apparently an allusion to the surname of Otis Redding.

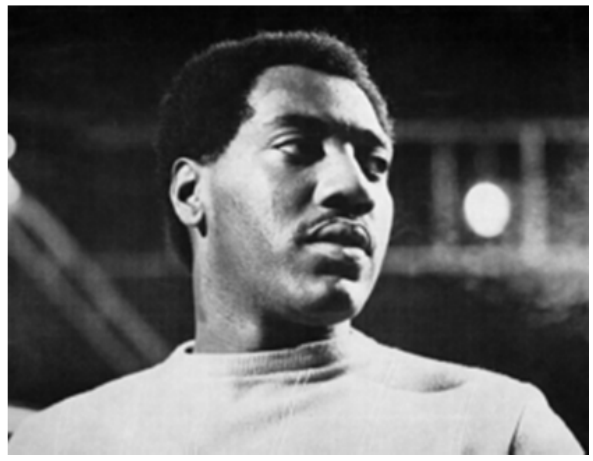

Fig. 9 
And now, the most interesting, in my opinion, the text of the song "L.A. Woman" from the eponymous album of 1971:

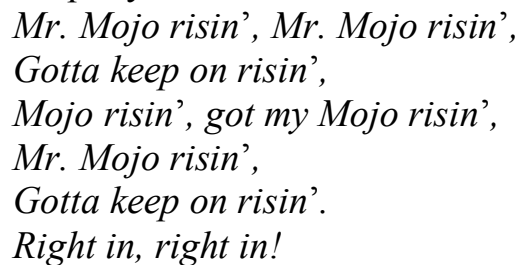

Who is "Mr. Mojo"? And why is he "risin"? Of course, it is a proper name, but still, who is he? As Peter Hogan writes in his "Guide...", Jim introduced the refrain of Mr. Mojo risin', bearing in his mind not only the meaning of "Mr. One risin" (lexeme mojo in American slang is used to replace forgotten names - such as Russian "Как его тал?"), but also gaming one, as this word is used "as a euphemism for concepts, often related to sex or drugs, although the value can be even wider, depending on the context. As it was discovered by John Sebastian, these words are the anagram of the name Jim Morrison, i.e., so that Jim made it clear that he continued to rise higher [7]. In other words: Jim Morrison > Mr. Mojo Risin'.

All this is quite likely. In general, it's a rather complex meaning expressed only with two words: "Mr. One, I mean it's me, sticking by sex and drugs and generally risin' higher and higher This is consistent with the selfperception by Morrison.

You can, however, also take into account such a version, basing on the combination got my Mojo risin' and the full context of the song "L.A. Woman". Mojo in American slang also refers to sexual potency [http://www.urbandictionary.com/define.php?term=Mojo].

And one more thing: Mojo (pronounced [m'odz'o]) is the Japanese name for "Morning star", i.e. Venus. It turns out like "the rise of Lord of Morning star". Not just too bad. In general, the speech game by Jim Morrison, as it's characteristic of him in general, produces a very complex semantic and symbolic configuration.

And finally, of course, in the lyrics by Jim Morrison, there are other feminine and masculine anthroponyms, but they are only in his poetic works that did not become songs. There is no point in analyzing them in this article, although when writing a forthcoming monograph on the language picture of the world by Jim Morrison in the appropriate paragraph, such examples are necessarily taken into account.

\section{Conclusion}

The versatility of the poetic and musical creativity of Jim Morrison conditioned the high complex frame of his linguistic picture of the world. It holds a special place in onomastics as one of the most important fragments 
of the national linguistic picture of the world: the way people are called reflect their attitude to the outside world. So anthroponymy is rising in many nations perceptions even to the pagan era, when people identified a word and object, themselves as persons and as a part of the world.

\section{References}

1. Sharifullin, B.Ya. (2015). "Five to one, one in five": The number images in the language picture of the world of Jim Morrison. Language and Culture. 3 (31). pp. 55-70.

2. Sharifullin, B.Ya. (2016). "Woman" in poetic discourse of Jim Morrison. The man and the language in communication and text. 7 (18). Krasnoyarsk: SFU. pp. 215-222.

3. Fevraleva, E.A. and Sharifullin, B.Ya. (2010). The Image of the Door in language picture of world of Jim Morrison' rock poetry. Interaction of the language and culture in communication and text. 10. Krasnoyarsk: SFU. pp. 115-119.

4. Sharifullin, B.Ya. (2014). The language picture of the world of "The Beatles": the cognitive and typological reconstruction. Saarbrucken: Lambert Academic Publishing. 216 p.

5. Fevraleva, E.A. (2010). The Image of the Ship and the Sea (the Way) in language picture of world of Jim Morrison. Student and scientific-technical progress: proceedings of XLVIII International scientific conference of graduate and undergraduate students (10-14 April 2010, Novosibirsk State University). Novosibirsk: NSU publishing house. pp.74-75.

6. Sharifullin, B.Ya. (2009). The proper name as a linguo-cultural symbol (on the material of texts of Britain rock poetry. The theoretical and applicative problems of modern philology. 9. Krasnoyarsk: SFU. pp. 121-127.

7. Hougen, P. (1994). The complex guide to the music of the Doors. Omnibus Press, $112 \mathrm{p}$.

8. Rybakin, A.I. (1984). The dictionary of English surnames. Moscow: Russian language. $576 \mathrm{p}$.

Resived 02.09.2016.

Information about the author

Sharifullin Boris - Doctor of Philology, Professor of Department of Russian Language and Literature, Faculty of Philology, Lesosibirsk Pedagogical Institute, Branch of Siberian Federal University (Lesosibirsk, Russian Federation). E-mail: borshariff@gmail.com 